\title{
Linguistic Interpretation of Russian Political Agenda Through Fake, Deepfake, Post-Truth
}

\author{
Anatoly P. Chudinov ${ }^{a}$, Natalya N. Koshkarovab \\ and Natalia B. Ruzhentseva* \\ ${ }^{a}$ Ural State Pedagogical University \\ 26 Kosmonavtov, Yekaterinburg, 620017, Russia \\ ${ }^{b}$ South Ural State University \\ 76 Lenin, Chelyabinsk, 454080, Russia
}

Received 19.09.2019, received in revised form 30.09.2019, accepted 07.10.2019

The paper examines the occurrences of fake, deepfake, and post-truth as destructive social phenomena from the linguistic point of view. The current situation with the amount of untruths said, euphemisms for lies used, facts withheld by those who do politics and write about it makes the study of the destructive social phenomena of special importance. The aim of the present study is to outline the linguistic factors influencing the process of fake news and deepfakes' formation. The materials containing hoax information about Russia and its activities on the international arena serve as the research basis for the analysis. The rebuttal published on the site of the Ministry of Foreign Affairs of the Russian Federation are also analysed in order to differentiate false information and true one. The methods of linguopragmatic, discursive and linguoculturological analysis, as well as contextual study of communicative situations are used. The authors present an extended typology of pragmatic and proper speech methods and means specific to text formation of fake news and deepfakes. The definition of fake news is given. Deepfakes are another mendacious genre form in the intercultural political space. The borderline is marked between fake news, deepfakes, and post-ruth. Some rules how to distinguish fake news (deepfake) from truth are given. The conclusion is made that the destructive social phenomena under study are not innocuous forms of entertainment, they represent a real social threat to anyone who is exposed to them, they do have political consequences, and they violate the main principle of journalism - "it's impossible to show what doesn't exist".

Keywords: fake, deepfake, post-truth, hoax, manipulation, destructive social phenomena.

This publication was prepared with the support of the Russian Foundation for Basic Research: Project 19-012-00465/19 "Linguopolitical Personology: A Cognitive Turn".

Research area: philology.

(C) Siberian Federal University. All rights reserved

* Corresponding author E-mail address: studiumjuvenis@mail.ru

ORCID: 0000-0001-5436-5273 (Chudinov); 0000-0001-8861-0353 (Koshkarova); 0000-0002-1208-1202 (Ruzhentseva) This work is licensed under a Creative Commons Attribution-NonCommercial 4.0 International License (CC BY-NC 4.0). 
Citation: Chudinov, A.P., Koshkarova, A.A., Ruzhentseva, N.B. (2019). Linguistic interpretation of Russian political agenda through fake, deepfake, post-truth. J. Sib. Fed. Univ. Humanit. Soc. Sci., 12(10), 1840-1853. DOI: 10.17516/1997-1370-0492.

\section{Introduction}

The problem of fake news and post-truth has garnered substantial attention of linguists recently. The scientists investigate different aspects of the phenomena under study: creating and disseminating fake news in the modern media (Allcott, Gentzkow, 2017; Botei, 2017; Sukhodolov, Bychkova, 2017), the concept of post-truth in its social and linguistic dimension (Böcskei, 2017; Koretskaya, 2017; Tallis, 2016), the difference between fake news and post-truth (Berendeev, 2017; Chugrov, 2017; Chesney, Citron, 2019). In the era when it's difficult to separate truth from fiction deepfake technologies are being widely implemented and discussed by men of letters (Waisbord, 2018; Villasenor, 2019). Those concerned with the above-mentioned problems try to answer a spectrum of questions: where is the demarcation line between truth and fiction in political communication? what are the differences and similarities between the phenomena of post-truth and fake news? can one say that truth is not among the core values for some actors of political communication? is it legitimate in characterizing post-truth to talk about populism as a type of political consciousness?

Unless answers to these questions are obtained it would be hard or even impossible to avoid prevarication in creating and analyzing modern political reality. The word prevarication seems to be a good one to be used while describing the present state with truth and fiction among some of the modern politicians since it "does not usually mean outright lying, so much as a conscious effort to tell anything but the truth". It is connected with "answering questions one was not asked". It also "involves allowing oneself to be distracted, during the answer, and going off in some other direction so that one never does address the question asked" (Waterford, 2013).

The concept of a mendacious politician (which would have been an oxymoron a few decades ago) has come up to the forefront of the political communication studies, and "the practice has ranged from straight faced deceits to withholding the truth, either for personal or political gains or for precipitating an international situation to gain strategic dividends, some of which have had the most devastating consequences for the world" (Shehedul, Khan, 2017). The current situation with the amount of untruths said, euphemisms for lies used, facts withheld by those who do politics and write about it makes the study of the destructive social phenomena of special importance. 


\section{Methodology}

The aim of the present study is to outline the linguistic factors influencing the process of fake news and deepfakes' formation. The materials containing hoax information about Russia and its activities on the international arena serve as the research basis for the analysis. The empiric material determines the choice of the methods used for the analysis of the speech data. The methods of linguopragmatic, discursive and linguoculturological analysis, as well as contextual study of communicative situations were used. The research method was framed under the influence of Fairclough's three-dimensional model for Critical Discourse Analysis according to which there is a relationship between texts, interactions, and contexts (Fairclough, 2015). F. I. Budaya and Kazemian affirm that "under Fairclough's threedimensional model, one of textoriented forms of discourse analysis is to conduct a detailed textual analysis within the field of linguistics with the objective to understand how discursive processes operate linguistically in specific texts" (Budaya, Kazemian, 2016: 284). This set of critical discourse analysis research tools enables the scholar to get a pluralistic view on the social context, discourse, and the texts produced by the speakers. Another valuable advantage of the chosen methodology is that it comprises achievements of various disciplinary fields: "pragmatics, narratology and speech act theory" which argue that "texts are forms of social action that occur in complex social contexts" (International Encyclopedia of the Sociology of Education, 1997). For instance, the contextual analysis of the selected material "includes consideration of all extra-linguistic factors: time, place, sphere of activity, participants of the discourse, their social roles, the nature of their interrelations and cognitive characteristics of the participants of the discourse" (Shapochkin, 2013: 107). Thus, the combination of the above-mentioned methods allows us to summarize that the conclusions reached by us during the study are valid and relevant for the analyzed material.

\section{Research}

In this article, we first of all tried to present an extended typology of pragmatic and proper speech methods and means specific to text formation of fake news and deepfakes. Let us enumerate some of the means:

1. Indefinite or anonymous source of information (anonymous attribution).

2. Anonymous attribution of someone else's speech (it is not known when and where the statement / testimony was published, in what situation it was uttered).

3. Intention to exacerbate the situation. 
4. The planned negative reaction of the world community, these or those countries, groups of political actors or individuals.

5. Sensationalism or drawing attention to the subject / topic of the message.

6. Nonspontaneous, artificial, plotted character of the message.

7. Lack of credibility of the informational message and / or of the judgment that underlies the interpretation of the event, as well as of the arguments given to substantiate the thesis.

8. Minimization of factual arguments.

9. Substitution of factual arguments with emotional ones.

10. The use of a large number of arguments, opinions and evaluative pseudoarguments, the predominance of the argument ad hominem.

11. Intentional deviation from the laws of logic.

12. Subjective interpretation of facts by means of:

a) juggling with the facts;

b) ignoring the facts and the reliable information;

c) giving the probable nature to the message;

d) introducing labels and emotionally colored vocabulary;

e) use of paralogical means of influence on the addressee;

f) using the tools of trash-journalism;

d) second-guessing someone else's speech, thoughts, and intentions.

13. Enhancing the authenticity of the message by means of:
a) compliance with the external logic of statements;
b) references to authorities and media figures;
c) using shock schemes.

The researchers single out the following characteristic features of trash-journalism:

1. The content is determined by the everyday culture. The reality is investigated not within the framework of the "man — objective" system, but in within the "man daily routine" system. It does not matter who the documentary hero is - a celebrity, a common person or a historical person.

2. The body needs and sordid desires are appealed to.

3. The scandalous and hideous aesthetics dominates.

4. The material that complies with the principles of sensationalism and extremity, pathology and perversion falls into the semantic field of the documentary television screen (Pochkai, 2012: 225). 
The same principles can be easily applied to the linguistic interpretation of the phenomenon of fake news which can be characterized as an alternative genre unit, where canonical versions of journalistic and political genres undergo significant modifications and transformations in definite discursive circumstances. In modern conditions of existence (mass media and electronic media), the prototype sample of the news genre is transformed, reduced, and receives new forms of implementation.

Let us examine how the characteristic features of the fake news message are manifested in some of the materials. The first publication under study is the article under the title Chess: a pawn in Russia's power game published in the Sunday edition of the Financial Times on April 4, 2019.

THE FACT WHICH SUMS UP THE CONTENT OF THE ARTICLE: the situation around the World Chess Federation (Fide) and the last-year election of its president.

THE CONTENT OF THE ARTICLE: In this material, Russia is charged with allegations of behind-the-scenes struggle, pressure on national delegations and intrigues, thanks to which, according to the author, Russia continues to occupy leading positions in the chess world.

THE REBUTTAL PUBLISHED ON THE SITE OF THE MINISTRY OF FOREIGN AFFAIRS OF THE RUSSIAN FEDERATION (April 26, 2019):

On April 4th this year in the Sunday edition of the British "Financial Times" the so-called. "journalistic investigation" of the situation around the International Chess Federation (FIDE) and last year's election of the head of this organization was published.

In this material, charges have been brought against our country in the dull struggle, pressure on national delegations and intrigues, thanks to which, according to the author, Russia continues to occupy a leading position in the chess world.

The great Soviet grandmaster M. M. Botvinnik was right when he said that chess players live and act in a world riddled with politics.

It seems that the gentlemen of the Financial Times judge by themselves. Russia has no need to resort to the methods they described - our country rightfully belongs to the number of leading chess powers. Alexander Alekhin, Mikhail Botvinnik, Vasily Smyslov, Viktor Korchnoi, Anatoly Karpov, Garry Kasparov, Vladimir Kramnik, Sergey Karyakin - the whole world knows the names of these great Russian and Soviet chess players.

We do not accept claims about the "pressure" on national delegations either, which allegedly were carried out by the Russian Foreign Ministry. Informing partners 
about a national candidate for a particular position in an international organization is a common and wide-spread practice. The organization of such work is one of the direct professional duties of both Russian and any other diplomats, in the context of FIDE as well. Seeing such work as "pressure" means crossing the line between responsible journalism and outright propaganda.

We consider the article in the Financial Times as another inappropriate attempt to politicize this game, which does not meet the interests of the global chess community. By releasing such fakes, the Financial Times simply fulfills the order of the British establishment and works to increase the "toxicity" of the information background around Russia. And this is done to the detriment of an objective and unbiased coverage of events in the field of sport, this time - chess one.

As it is seen from this rebuttal, it contains the appeal to the precedent names and utterances, proofbycontradiction, theusage of arguments adrem. Y. V. Bogoyavlenskaya, E. A. Nakhimova, A.P. Chudinov point out that "the perception of a precedent event is often defined by axiological characteristics which can also depend on the requirements of the present moment, the social atmosphere, the author's political views and the aims of the concrete publication" (Bogoyavlenskaya, Nakhimova, Chudinov, 2016: 40). In the case under discussion the names of chess grandmasters (M. Botvinnik, A. Alekhin, V. Smyslov, A. Karpov, G. Kasparov, S. Karyakin and others) serve as an embodiment of cultural and historical values, a means of uniting Russian people on common mental and verbal grounds. Another rhetorical tool used in the rebuttal is the proof by contradiction, or the negation of the fact which was described in the original article - Russia has no need to resort to the methods they described - our country rightfully belongs to the number of leading chess powers. Russia is charged with allegations of using backstairs methods both in politics and sport; the aim of the rebuttal is to deny these charges and give some evidence of the opposite situation. And finally, arguments ad rem are used with the purpose of overcoming the emotional pressure on the recipient to implement the programmed reaction provoked by the fake news.

\section{FAKE ATTRIBUTES OF THE ARTICLE}

Attribution of the publication - the British newspaper Financial Times.

Anonymous attribution of the people whose opinions and testimonies serve as the evidence basis for charges brought against Russia:

Documents seen by the Financial Times and extensive interviews with more than a dozen senior figures in the chess world show a co-ordinated global effort by the 
Russian state, through ambassadors and representatives of its banks and biggest companies, to win votes with promises of money and political pressure.

According to senior western diplomats, wiretaps revealed Ilyumzhinov had set up a bank in Russia to process payments on behalf of Syrian intermediaries working for the Assad family.

Of Fide's 189 federations, Makropoulos says, "more than 120 federations got pressure, either direct, by Russian embassies, or through their ministers of sport, or even ministers of foreign affairs."

As it is seen from the given examples no particular names of 'senior figures', 'senior western diplomats' or 'Fide's federations' are given. One should be aware of the fact that anonymous attribution is one of the main characteristics of fake news and it is contradictory to the core principle of journalism which consists in "dependable attribution, assigning information to a specific source" (Fromm, Hall, Manfull, 2015: 393). D. A. Barclay goes even further than this and states that "when an anonymous source is being used in a legitimate way, the creator of the information should acknowledge that the source is anonymous and provide explanation as to why the source cannot be disclosed" (Barclay, 2018: 76).

Anonymous source of information:

Fide documents reveal years of unsound financial practices, raising red flags about the flow of money to and from Fide officials and third-party companies and trusts run by them.

Dozens of documents seen by the FT from three well-placed Fide sources reveal years of unsound financial practices at the organisation, which are sufficient to raise serious ethical red flags.

Lack of factual arguments:

According to Makropoulos, "dozens" of federations were also swayed by gifts and incentives.

In the run-up to the election in Batumi, Georgia, some federations received a WhatsApp message from Berik Balgabaev, a former assistant to Ilyumzhinov now working for Dvorkovich. The message contained a template letter, to be sent to a specified address at Gazprombank, to obtain money.

It wasn't just money that the Russian camp offered. A crucial clutch of votes in the election ended up coming from an unexpected source: one of the Kremlin's most vociferous and ardent critics, former world chess champion Garry Kasparov. Makropoulos alleges that Kasparov lent his support to the Dvorkovich campaign — via 
that of Nigel Short, who he believed ran as a stalking horse - on the expectation that potentially lucrative commercial sponsorship rights for the World Chess Championship would be transferred to a new venture Kasparov planned to set up.

Thus the article under discussion contains all characteristics of fake news the main aim of which is to ruin the image of the country, namely Russia on the world arena through the discussion of the topic which is inseparable from politics, i. e. sport. The latter has recently been greatly influenced by the political events and there has been a merge of sport and political discourse. The main intention of the article as fake news is to escalate the tension in the relations of Russian with the major global powers through full or partial anonymous character of the message addressees, anonymity of the media vehicle on which the statements underlying the publication were placed, and lack of factual information.

Now let us examine the type of material which can be considered as an example of deepfake which is "highly realistic and difficult-to-detect digital manipulations of audio or video" (Chesney, Citron, 2019: 147). The technology that allows the creator of deepfakes to put any words into the mouth of any person on the video, to show the events which have never taken place so that it is impossible to detect a fake from truth is considered the most dangerous information weapon of our time. Experts and legislators predict that the high-tech way to "put words into someone's mouth" will become the most modern weapon in the context of information and psychological warfare.

That's the case with the programme Dirty Money featured by the Australian "Channel 7" on July 29, 2018 featuring William Browder, CEO of Hermitage Capital Management.

THE FACT WHICH SUMS UP THE CONTENT OF THE PROGRAMME: Russian 'dirty money' hidden in Australian assets and laundered through some financial institutions is damaging the ability of some key political and business figures to stand firm against Moscow's increasingly aggressive foreign policy.

THE CONTENT OF THE PROGRAMME: Bill Browder gives the "proof" that Vladimir Putin, the President of Russia, uses Australia as a location to launder mafia money, which has made the billionaire businessman Putin's public enemy number one.

THE REBUTTAL PUBLISHED ON THE SITE OF THE MINISTRY OF FOREIGN AFFAIRS OF THE RUSSIAN FEDERATION (August 9, 2018):

Australian "Channel 7" aired its "Dirty Money" show on July 29 featuring William Browder, CEO of Hermitage Capital Management, who was charged with tax evasion, failure to comply with the duties of a tax agent and deliberate bankruptcy by Russia's 
investigative authorities. Once again, Mr. Browder, without citing specific facts and just referring to alleged evidence, accused Russia's leadership of involvement in money laundering. Matt Doran, the show's host, instead of trying to sort out this complicated matter, built his “investigative report” solely on supporting Browder's accusations. The programme left the impression of a propaganda-based thriller, where Russians speak with an accent, and the source of so-called revelatory videos is unknown. Of course, Mr. Browder was portrayed as "Vladimir Putin's victim." This story was further aggravated by the now traditional speculations in the Western media around the cases of Litvinenko, Skripal, Magnitsky and Perepelichny. As always, without trial or investigation, without facts or evidence, Russia and Vladimir Putin personally are to blame for everything.

The Australian television programme didn't mention it, but we would like to fill the gap and remind everyone that Mr. Browder stole over $\$ 1.5$ billion from Russia and was convicted twice in 2013 and 2017. In February 2018, another criminal case was opened against him by the Russian investigative authorities, which, among other things, focuses on his attempted perjury in a US court during the US versus Prevezon hearings. Browder's activities were commented upon in detail by Foreign Ministry Deputy Spokesman Artyom Kozhin at a briefing on July 26.

In general, this Australian TV show is another example of biased anti-Russia propaganda where the result of a "journalistic investigation" was predetermined, the word was given primarily to one side, the "accuser" (the arguments provided by political scientist Alexander Nekrasov were deliberately ridiculed by the journalist, and Nekrasov was given almost no airtime), while a frightening image of Russia was created through footage manipulation, among other things.

Dirty Money is a vivid example of the professional degradation of Australian television, which willingly gave the floor to William Browder, a businessman with a stained reputation.

\section{FAKE ATTRIBUTES OF THE MATERIAL}

Lack of specific facts alongside with the aggressive illocutionary intention:

"I think he is worth about US\$200 billion," Browder tells Sunday Night. "All his money is the proceeds of crime. Putin is not only the richest man in the world, he is the most powerful crime lord in the world as well."

But Browder believes it was something more sinister. "I believe he (Alexander Perepelichny) was poisoned."

In March, the Russians unleashed their deadliest toxin yet in the quiet English town of Salisbury. 
As it is seen from the given examples, one of the frequently used speech tactics in fake news is "labelling" in relation to a specific historical period or the people when qualities and (or) signs that are not peculiar to the object, or characteristics inherent to the object in an insignificant degree are generalized or hypertrophied. Labelling in fake news goes hand in hand with hate speech which, alongside with intolerance, "has become part of political discourse, where it is used not only by populist and extremist groups but increasingly by representatives of movements and parties across the political spectrum" (Kovács, 2019: 2).

Increased emotional character of the text in order to substitute the logical argumentation by emotional one:

Browder is about to blow the lid on a massive money-laundering scheme, a trial of blood mud that runs from the Kremlin to London and the way to Australia.

Russia has a history of executing its enemies on foreign soil.

They don't forgive, they don't forget, and they will track you down anywhere in the world, they will kill you.

The host of the programme assumes that political scientist Alexander Nekrasov uses the same "bizarre" logic to deny any Kremlin involvement in the deaths of either Sergey Magnitsky or Alexander Perepelichny. The death of Alexander Litvinenko is called a "notorious execution", "a state-sponsored act of terror on UK soil by the FSB", an "audacious killing".

\section{DEEPFAKE ATTRIBUTES OF THE MATERIAL}

The host of the programme Matt Doran tries to restore the situation with Alexander Litvinenko's poisoning with radioactive polonium 210 and shows how "the killers retreat and tip the rest of the deadly liquid solution down the bathroom sink". He states that "the hit men leave a trail of radioactive crumbs behind them, it's even found on their seats on a British Airways flight that leads all the way back to Moscow".

The material is accompanied with the scenes of Sergey Magnitsky's (a "gutsy lawyer", as the host of the programme calls him) arresting and throwing in jail. Browder comments on this situation: "They wanted to get him to sign a false confession to say that he stole the 230 million dollars ...". W. Browder insists that instead of putting Magnitsky in an emergence room they put them in an isolation cell, they chained him to a bed, made riot guards with rubber batons beat him to death.

There is a scene of two key players who "exposed Russia's biggest ever tax fraud, one of whom (Sergey Magnitsky) was beaten to death in a prison and the other (Alexander Perepelichny) is believed to have been poisoned. 
The material ends with a statement that "more than a dozen of Vladimir Putin's enemies have died mysterious deaths in Britain, especially those who have threatened his secret fortune".

Thus, this material can, from our point of view, be rightfully classified as fake messages. The fake character of its textual formation is achieved: a) by lack of specific facts alongside with the aggressive illocutionary intention; b) by means of increased emotional character of the text; c) by the usage of deepfake technologies.

\section{Discussion}

The linguistic analysis of fake news and deepfake let us come to the conclusion that they represent a genre representation of a misrepresented reality in the intercultural political space. Despite the general characteristic features - a depiction of what does not exist in reality - post-truth is a more global phenomenon than fake news and deepfake. Post-truth is a breeding ground for creating fake news and deepfake, which are constructed according to certain canons and rules, using propaganda and manipulative influence mechanisms. The lack of censorship on the Internet leads to an increase in the number of inaccurate messages that are being dealt with at different levels, and a common user should be able to distinguish fake from truth.

Below are some of the rules how to distinguish fake (deepfake) from truth:

1) pay attention to the number of reprints: "the number of reprints in the case of an unnatural reason skyrockets at a meager number of originals" (Belyaev, 2015:178-179);

2) check who this or that material or information belong to: "there is always a certain person or organization behind any serious material” (Belyaev, 2015:178-179);

3) analyze the text from a linguistic point of view: the presence of stock phrases, the reproduction of information, the absence of a direct reference to the source of information and (or) the original indicates an information attack;

4) check the authenticity of photos: for this purpose one can use a huge amount of resources: http://www.findexif.com, http://www.fotoforensics.com/, http://netler.ru/ikt/ google-search-image.htm,

5) be a demanding and sophisticated reader: do not trust catchy headlines, fabricated stories, unverified information, but rely on your experience, existing knowledge and analysis of the current geopolitical situation.

Fake news, deepfake, and post-truth can be defined in various ways but those who deal with these social destructive phenomena should admit the fact: in spite of different sources of origin, miscellaneous motivation for providing this type of information, it 
is not an innocuous form of entertainment, it is a real social threat to anyone who is exposed to it, it does have political consequences, and it violates the main principle of journalism — “it's impossible to show what doesn't exist”.

\section{References}

Allcott, H., Gentzkow, M. (2017). Social media and fake news in the 2016 election. In Journal of Economic Perspectives, 31 (2), 211-236.

Barclay, D.A. (2018). Fake news, propaganda, and plain old lies. Lanham, Rowman and Littlefield, $248 \mathrm{p}$.

Belyaev, D. (2015). Razrukha v golovakh. Informatsionnaia voina protiv Rossii [Disorder in the heads. Information war against Russia]. Saint Petersburg, Peter, $256 \mathrm{p}$.

Berendeev, M.V. (2017). Inversiia obraza strany i politika postpravdy v mediǔnom diskurse (Rossiia v pol'skom keǐse) [Inversion of the image of the country and the policy of post-truth in media discourse (Russia in the Polish case)], In Post-truth policy in the modern world, 24-27.

Böcskei, B. (2017). "Post-truth politics" as the normal state of politics. In TamaraJournal for Critical Organization Inquiry, 15(3-4), 257-260.

Bogoyavlenskaya, Y.V., Nakhimova, E.A. \& Chudinov, A.P. (2016). Precedent utterances in the national historical memory: a corpus study. In Voprosy Kognitivnoy Lingvistiki, 2 (47), 39-48.

Botei, M. (2017). Misinformation with Fake News. In Bulletin of the Transilvania University of Braşov. Series VII: Social Sciences. Law, 10 (59), 2, 133-140.

Budaya, F.J., Kazemian, B. (2016). Obama's speech at climate change conference COP 21 in Paris in 2015: Fairclough's three-dimensional model. In Jurnal Sosioteknology, 15(2), 282-290.

Chesney, R., Citron, D. (2019). Deepfakes and the new disinformation war. The coming age of post-truth geopolitics. In Foreign Affairs, January / February, 147-155.

Chugrov, S.V. (2017). Post-truth: transformatsiia politicheskoř real'nosti ili samorazrushenie liberal'noi demokratii [Post-truth: the transformation of political reality or the self-destruction of liberal democracy]. In Polis. Political studies, 2, 42-59.

Fairclough, N. (2015). Language and power. (3rd ed.). London and New York, Routledge, 274 p.

Fromm, M., Hall, H.L. \& Manfull, A. (2015). Student journalism and media literacy. New York, The Rosen Publishing Group, 352 p. 
International Encyclopedia of the Sociology of Education (1997). Available at: https://pages.gseis.ucla.edu/faculty/kellner/ed270/Luke/SAHA6.html (accessed 23 March 2019).

Kovács, E. (2019). The role and responsibilities of political leaders in combating hate speech and intolerance. In Parliamentary Assembly, March 12, 2-14.

Koretskaya, O.V. (2017). Feǐkovye novosti kak ob"ekt izucheniia medialingvistiki [Fake news as an object of studying medialinguistics]. In Philological sciences. Issues of theory and practice, 9 (75), 1, 118-120.

Pochkai, E.P. (2012). Televidenie v «adrenalinovoĭ upakovke», ili èkstremal'noena teleèkrane [Television in "adrenaline packaging”, or extreme on TV]. In Leisure journalism, 220-228.

Shapochkin, D.V. (2013). Metod kognitivnogo analiza diskursa v lingvistike [Method of cognitive analysis of discourse in linguistics]. In Bulletin of Chelyabinsk State University, 10 (301), 76, 101-107.

Shehedul, B.G., Khan, A. (2017). The mendacious US presidents. In The Daily Star, May 18.

Sukhodolov, A.P., Bychkova A.M. (2017). «Feǐkovye novosti» kak fenomen sovremennogo mediaprostranstva: poniatie, vidy, naznachenie, mery protivodeǐstviia ["Fake news" as a phenomenon of modern media space: the concept, types, purpose, countermeasures]. In Theoretical and practical issues of journalism, 6(2), 143-169.

Tallis, B. (2016). Living in post-truth: power, knowledge, responsibility. In New Perspectives, 24(1), 7-18.

Villasenor, J. (2019). Artifical intelligence, deepfakes, and the uncertain future of truth. Available at: https://www.brookings.edu (accessed 5 May 2019).

Waisbord, S. (2018). Truth is what happens to news: on journalism, fake news, and post-truth. In Journalism Studies, 19(13), 1866-1878.

Waterford, J. (2013). Politicians are known to use facts to obscure the truth. In The Sydney Morning Herald. December 8.

\section{Sources of information}

Jones, S. (2019). Chess: a pawn in Russia's power. In The Financial Times, April 4.

Matt, D. Dirty Money (2018). Available at: https://www.youtube.com/ watch?v=yVsqJ8XQ7mw (accessed 4 May 2019).

Published materials that contain false information about Russia. Available at: http://www.mid.ru/en/nedostovernie-publikacii (accessed 1 May 2019). 


\title{
Лингвистическая интерпретация политики России через призму фейка, дипфейка, постправды
}

\author{
А.П. Чудинова ${ }^{a}$ Н.Н. Кошкарова \\ Н.Б. Руженцева ${ }^{a}$ \\ ${ }^{a}$ Уральский государственный педагогический университет \\ Россия, 620017, Екатеринбург, пр. Космонавтов, 26 \\ ${ }^{6} Ю$ жн-Уральский государственный университет \\ Россия, 454080, Челябинск, пр. Ленина, 76
}

Статья посвящена лингвистическому анализу фейка, дипфейка и постправды как деструктивных сочиальных явлений. Текущая ситуация, когда произносится столько неправды, используется такое количество эвфемизмов для описания лжи, утаиваются факты политиками и теми, кто анализирует политику, делает изучение указанных деструктивных социальных явлений особенно актуальным. Целью настоящего исследования служит описание лингвистических механизмов создания фейка и дипфейка. Материалом для исследования послужили публикации, содержащие недостоверную информацию о России и ее деятельности на международной арене. Также анализируются публикачии, расположенные на сайте Министерства иностранных дел РФ, опровергающие указанные недостоверные публикации. В ходе исследования используются методы лингвопрагматического, дискурсивного, лингвокультурологического анализа, а также контекстуального изучения коммуникативных ситуаций. Авторы предлагают расширенную типологию прагматических и собственно речевых средств, характерных для текстообразования фейковых сообщений и дипфейков; дают определение фейковых новостей; рассматривают дипфейки как ещче один «ложный» жанр в межкультурном политическом пространстве; проводят гранииу между фейками, дипфейками и постправдой, а также дают несколько советов, как отличить фейки (дипфейки) от правды. Вывод заключается в том, что указанные деструктивные социиальные явления - это не безобидная форма развлечения, а реальная угроза для тех, кто сталкивается с ними, что они имеют серьезные политические последствия и нарушают главный принцип журналистики — «невозможно показать то, чего нет».

Ключевые слова: фейк, дипфейк, постправда, ложь, манипуляция, деструктивные соичиальные явления.

Публикачия подготовлена при поддержке Российского фонда фундаментальных исследований: проект 19-012-00465/19 «Лингвополитическая персонология: когнитивный поворот».

Научная специильность: 10.00.00 - филологические науки. 